\title{
POTENTIAL OF SALVINIA MOLESTA IN TREATMENT OF TEXTILE
}

\section{WASTE WATER}

\author{
Pavithra $M^{1}$, Hina Kousar ${ }^{2}$, Dhanushree.M.S ${ }^{3}$, Navitha.K.R ${ }^{4}$, Akshata.K.U ${ }^{5}$, Shivraj.S ${ }^{6}$ \\ ${ }^{I}$ Research Scholars, Department of P.G Studies and Research in Environmental Science, Kuvempu University, Jnana \\ Sahyadri, Shankaraghatta-577 451, Karnataka, India \\ ${ }^{2}$ Assistant Professor, Department of P.G Studies and Research in Environmental Science, Kuvempu University, Jnana \\ Sahyadri, Shankaraghatta-577 451, Karnataka, India \\ ${ }^{3}$ Research Scholars, Department of P.G Studies and Research in Environmental Science, Kuvempu University, Jnana \\ Sahyadri, Shankaraghatta-577 451, Karnataka, India \\ ${ }^{4}$ Research Scholars, Department of P.G Studies and Research in Environmental Science, Kuvempu University, Jnana \\ Sahyadri, Shankaraghatta-577 451, Karnataka, India \\ ${ }^{5}$ Research Scholars, Department of P.G Studies and Research in Environmental Science, Kuvempu University, Jnana \\ Sahyadri, Shankaraghatta-577 451, Karnataka, India \\ ${ }^{6}$ Research Scholars, Department of P.G Studies and Research in Environmental Science, Kuvempu University, Jnana \\ Sahyadri, Shankaraghatta-577 451, Karnataka, India
}

\begin{abstract}
Phytoremediation is an emerging technology that uses green plants for removal of contaminants of concern(COC)( M. Hazra et al., 2015). In the present study, Salvinia molesta was used to determine its potential to clean up contaminants from textile waste water. Parameters like pH, Colour, Biochemical Oxygen Demand (BOD 5 ), Chemical Oxygen Demand (COD), Nitrate Nitrogen, Electrical Conductivity (EC), Total hardness and the metals, Iron $(F e)$, Copper and Fluoride were analyzed using standard laboratory procedures. Results showed considerable reduction in all parameters and Analysis of Variance(ANOVA) revealed statistically significant relationship. S.molesta has proved effective in treatment of textile wastewater.
\end{abstract}

Keywords: Phytoremediation, contaminants of concern(COC), textile waste water, Salvinia molesta $* * *$

\section{INTRODUCTION}

Textile dyes and effluents are considered as one of the worst polluters of water and soil. They are well known mutagens and carcinogens posing a threat to all life forms (Khandare et al., 2015). Textile wastewater contains substantial pollution loads in terms of Chemical Oxygen Demand (COD), Biological Oxygen Demand (BOD), Total Suspended Solids (TSS), Total Dissolved Solids (TDS) and heavy metals (Mahamood et al., 2005). The impact on the environment by textile industry has been recognized for some time, both in terms of the discharge of pollutants and of the consumption of water and energy (Lacasse and Baumann, 2006).

Traditional wastewater treatment technologies have proven to be markedly ineffective for handling wastewater of synthetic textile dyes because of the chemical stability of these pollutants( Muthunarayanan et al., 2011). The use of plants to degrade, assimilate, metabolize or detoxify contaminants is cost effective and ecologically sound. Phytoremediation is one of the remediation method which involves the use of plants to treat environmental pollutants (Akinbile and Yusoff, 2012; Sachdeva and Sharma, 2012). Plants are especially useful in the process of bioremediation because they prevent erosion and leaching which can spread the toxic substances to surrounding areas (Jones et al., 2006;
USEPA 2001). Several aquatic plants have been used to treat industrial wastewater with good results (Akinbile et al., 2016). Photosynthetic activity and growth rates of plants are the keys to economic success of phytoremediation.

The plant used for the present study is Salvinia molesta ,which is a free-floating fern that forms dense mats on water. This plant is currently employed in many parts of the world for heavy metal water purification purposes and has shown promising results for the degradation of organic and inorganic load from contaminated water sources (Odjegba and Fasidi, 2004; Gupta et al., 2012). It has been shown that highly concentrated effluents from various industries may not be suitable for plant growth in undiluted conditions (Trivedy and Gudekar, 1985). So, the use of different concentrations of effluent will help to assess the treatment efficiency. The aim of the present study was to determine the potential of Salvinia molesta in reducing the pollution load of textile wastewater to meet water quality standards.

\section{MATERIALS AND METHODS}

\subsection{Collection of Plants}

Salvinia molesta was collected from a natural pond near Shimoga. Same sized young and healthy plants were 
collected and acclimatized in laboratory conditions for three days. Later they were introduced into the effluent.

\subsection{Method}

Different concentrations $(25 \%, 50 \%, 75 \%$ and raw) of effluent were used for treatment, while the control was maintained separately. Plastic troughs of 10 litre capacity were filled with 7 litre of different concentrations of effluent. The plants were allowed to grow in laboratory model ponds for 7 days, after which they were taken out and the plant treated effluent was analyzed for the efficiency of Salvinia molesta in reducing physico-chemical parameters.

\subsection{Wastewater Characterization}

The sample for the analysis was collected from a textile industry near Shimoga and brought to the laboratory and analysed for various physico-chemical parameters using standard laboratory procedures.

Concentration of the dye was analyzed using UV-visible spectrophotometer at $\lambda \max$. BOD of the effluent was analyzed by incubating the sample at $20^{\circ} \mathrm{C}$ for 5 days(IS: 3025 P44) (APHA 2009), COD was determined by using closed reflux method. Hardness was determined using EDTA titrimetric method. $\mathrm{pH}$ and conductivity of the samples was recorded using ELICO 172 Soil and Water analysis kit. Total Nitrate Nitrogen concentration was measured by cadmium reduction method. The metals, Iron (Fe) was determined by Thiocyanate method, Copper(Neo Cuproin method) and Flouride(SPADNS method).

\subsection{Data Analysis}

Results are expressed as mean \pm SEM. The statistical analysis was carried out using one way ANOVA followed by Tukey's t-test. The difference in values at $\mathrm{p}<0.05$ or $\mathrm{p}<0.01$ were considered as statistically significant.
Statistical analysis was performed using ezANOVA 0.98 version.

\section{RESULT AND DISCUSSION}

\subsection{Characterization of Textile Wastewater}

Table 1 Initial wastewater characterstics of textile wastewater

\begin{tabular}{|l|l|l|}
\hline Parameters & $\begin{array}{l}\text { Observed } \\
\text { Values }\end{array}$ & BIS limits \\
\hline Temperature & $50^{0} \mathrm{C}$ & $<40^{0} \mathrm{C}$ \\
\hline $\mathrm{pH}$ & 9.07 & $5.5-9$ \\
\hline Color(Pt-Co) & $2595 \pm 5$ & 25 \\
\hline COD $(\mathrm{mg} / \mathrm{L})$ & $1295 \pm 5$ & 250 \\
\hline BOD(mg/L) & $326.66 \pm 25.16$ & 100 \\
\hline $\begin{array}{l}\text { Electrical } \\
\text { Conductivity }\end{array}$ & $6173.3 \pm 25.16$ & 600 \\
\hline $\begin{array}{l}\text { Total } \\
\text { Hardness(mg/L) }\end{array}$ & $173.5 \pm 0.50$ & 500 \\
\hline $\begin{array}{l}\text { Nitrate } \\
\text { Nitrogen(mg/L) }\end{array}$ & $0.4 \pm 0.095$ & 10 \\
\hline TotalIron(mg/L) & $1.76 \pm 0.25$ & 5 \\
\hline Copper(mg/L) & $0.17 \pm 0.03$ & - \\
\hline Fluoride(mg/L) & $0.16 \pm 0.02$ & $0.5-1$ \\
\hline
\end{tabular}

Table 1 shows initial characteristics of the 11 parameters considered for analysis in the study. With the exception of $\mathrm{pH}$, Total Hardness, Nitrate, Copper, Iron and Fluoride which had values within and below the standard discharge limit, all other parameters like color, $\mathrm{BOD}_{5}, \mathrm{COD}$ and $\mathrm{EC}$ exceeded the standard limits. $\mathrm{pH} 9.07$ was within the permissible limit, Fe concentration $1.76 \pm 0.25 \mathrm{mg} / \mathrm{L}$ was less than the tolerable limit $5 \mathrm{mg} / \mathrm{L}$ (BIS) and Nitrate nitrogen, Copper and Fluoride were far lower than the permissible limit. EC values of $6173.3 \pm 25.16 \mu \mathrm{mhos} / \mathrm{cm}$ was far higher than the tolerance limit of $1000 \mu \mathrm{mhos} / \mathrm{cm}$.

Table 2 Concentration of effluent after treatment with Salvinia molesta

\begin{tabular}{|c|c|c|c|c|c|}
\hline \multirow[t]{2}{*}{ Parameters } & \multirow[t]{2}{*}{ Units } & \multicolumn{4}{|c|}{ After treatment(7 days) } \\
\hline & & Raw effluent & $75 \%$ concentration & $\begin{array}{l}\mathbf{5 0 \%} \\
\text { concentration }\end{array}$ & $\begin{array}{l}25 \% \\
\text { concentration }\end{array}$ \\
\hline Color & $\mathrm{Pt}-\mathrm{Co}$ & $1377 \pm 2.65 * *$ & $895.33 \pm 5.03 * *$ & $719.33 \pm 3.06^{* *}$ & $410 \pm 9.17 * *$ \\
\hline COD & $\mathrm{mg} / \mathrm{L}$ & $1100 \pm 100^{*}$ & $811.67 \pm 10.41 * *$ & $521.67 \pm 7.64 * *$ & $305.67 \pm 6.03 * *$ \\
\hline BOD & $\mathrm{mg} / \mathrm{L}$ & $276 \pm 5.29 *$ & $103.33 \pm 7.57 * *$ & $65 \pm 3 * *$ & $42.33 \pm 2.52 * *$ \\
\hline $\begin{array}{l}\text { Electrical } \\
\text { Conductivity }\end{array}$ & $\begin{array}{l}\mu \\
\mathrm{mhos} / \mathrm{cm}\end{array}$ & $5010.67 \pm 10.07 * *$ & $4318 \pm 2 * *$ & $2858 \pm 2 * *$ & $1120 \pm 2 * *$ \\
\hline Total Hardness & $\mathrm{mg} / \mathrm{L}$ & $98 \pm 2 * *$ & $77.67 \pm 2.52^{* *}$ & $66.33 \pm 1.53^{* *}$ & $42.67 \pm 2.52 * *$ \\
\hline Nitrate Nitrogen & $\mathrm{mg} / \mathrm{L}$ & BDL & BDL & BDL & BDL \\
\hline Total Iron & $\mathrm{mg} / \mathrm{L}$ & BDL & BDL & BDL & BDL \\
\hline Copper & $\mathrm{mg} / \mathrm{L}$ & BDL & BDL & BDL & BDL \\
\hline Flouride & $\mathrm{mg} / \mathrm{L}$ & BDL & BDL & BDL & BDL \\
\hline
\end{tabular}

Note: BDL-Below Detectable Level

Values are expressed as mean $\pm \operatorname{SEM}(n=3)$, *p<0.05; **p<0.01, denotes significance with respect to initial values(before treatment) using one way ANOVA followed by Tukey's test. 
The results indicate that Salvinia molesta reduced the concentration of all the parameters to a significant level, but the reduction was higher in $25 \%$ concentration of the effluent than in others (Table2). The initial values in effluent for color before treatment was $2595 \pm 5$ and these values decreased appreciably to $1377 \pm 2.65$ ( raw effluent),

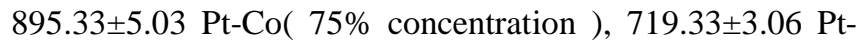
Co,( $50 \%$ concentration) and $410 \pm 9.17 \mathrm{Pt}-\mathrm{Co}$ ( $25 \%$ concentration). This is in agreement with the findings of Aziz et al., (2012) who made a similar observation in their studies.

Concentration of Nitrate nitrogen, Total Iron, Fluoride and Copper before treatment were $0.4 \pm 0.095,1.76 \pm 0.25$, $0.16 \pm 0.02$ and $0.17 \pm 0.03$ respectively and after treatment the values were below detectable level. This reflected tremendous uptake of these parameters by S.molesta.

BOD removal by S.molesta in different concentrations showed that it cannot perform well in raw effluent having high BOD value. Maximum BOD reduction was observed in $25 \%$ concentration. It indicates that dilution of wastewater enhances the performance of the test plant i.e. S.molesta.

Salvinia molesta shows maximum reduction of COD in $25 \%$ concentration and minimum in raw effluent. In $25 \%$ concentration, COD reduced from $1200 \mathrm{mg} / \mathrm{l}$ to $800 \mathrm{mg} / \mathrm{L}$.

As far as Conductivity is concerned, Salvinia molesta decreased the conductivity in all the concentrations. However, maximum reduction was seen in $25 \%$ concentration where it decreased from $6173.3 \pm 25.16 \mu$ mhos to $1120 \pm 2 \mu$ mhos.

The relationship between concentration of effluent before treatment and the rate of reduction in all the parameters agree with the findings of Rouf Ahmed et al.,(2010).

For all the parameters it has been found that S.molesta performed well in $25 \%$ concentration of the effluent. This indicates dilution enhances the performance of test plants in dye waste water. In raw effluent, plants were unable to acclimatize well probably due to the high concentration of toxic compounds that may have affected the test plants.

\section{CONCLUSION}

Experiments were conducted to evaluate the efficiency of S.molesta for the treatment of textile wastewater. The results revealed that all parameters analyzed including metals had considerably reduced in their concentration. S.molesta showed maximum performance in $25 \%$ concentration of the effluent .Dilution of the effluent may have made the uptake easy for the aquatic plant. Going by the results obtained, it is concluded that Salvinia molesta is a very reliable plant in treating textile wastewater.

\section{REFERENCES}

[1] Mahmood,Q., Zheng, P., Islam,E., Hayat,Y., Hassan, M,J., Jilani,G., and Jin,R,C. 2005. Lab Scale Studies on Water Hyacinth (Eichhornia crassipes Marts Solms) for Biotreatment of Textile Wastewater. Caspian J. Env. Sci. 3(2):83-88

[2] Khandare,R.V.,Govindwar,S.P. 2015 Phytoremediation of textile dyes and effluents: Current scenario and future prospects, Biotechnol Adv.

[3] Lacasse K., Baumann W., 2006. Textile Chemicals. Environmental Data and Facts, Springer.

[4] Muthunarayanan,V., Santhiya., M,Swabna,V., andGeetha, A.2011. Phytodegradation of textile dyes by Water Hyacinth (Eichhornia crassipes) from aqueous dye solutions. Int.J.Env Sci.1(7)

[5] Akinbile, O,C., Ogunrindea, T,A., Hasfalina Che Bt Man and Aziz,H.,A.2016. Phytoremediation of domestic wastewaters in free water surface constructed wetlands using Azolla pinnata. Int. J.phytoremediation. 18(1): 5461

[6] Schnoor, J,L., Licht, L,A., McCutcheon, S,C., Wolfe, N,L., Carreira, L,H.1995. Phytoremediation of organic and nutrient contaminants. J.Env.Sci.Tech, 29:318-323

[7] Akinbile, C,O., Yusoff, M, S., Ahmad Zuki, A,Z. 2012. Landfill leachate treatment using sub-surface flow constructed wetland by Cyperus haspan. Waste Manage. 32:13871393.

[8] Sachdeva S and Sharma A. 2012. Azolla: Role in Phytoremediation of Heavy Metals. Paper from Proceeding of the National Conference "Science in Media 2012" Organized by YMCA University of Science and Technology, Faridabad, Haryana (India) December 3rd4th 2012 Published by IJMRS's International Journal of Engineering Sciences, ISSN (Online): 2277-9698.

[9] Jones, D,L., Williamson, K,L., Owen, A,G. 2006. Phytoremediation of landfill leachate. Waste Manage. 26:825837.

[10] United States Environmental Protection Agency (USEPA). 2001. Constructed Wetland for Wastewater Treatment and Wildlife Habitat. Office of Research and Development, EPA 832-R-93-005.

[11] Trivedy, R., K. and Gudekar, V. R..1985. Water hyacinth for wastewater treatment: A review of the progress. Environmental Publications, Karad, India., $110-145$

[12] Odjegba, V,J. and Fasidi, I,O. 2004.Accumulation of trace elements by Pistia stratiotes: implications for phytoremediation. Ecotoxicology.13(7):637-46.

[13] Rouf Ahmad S, Kumawat, D.M., Nihal Singh and Khursheeed Ahmad Wani. 2010.Water hyacinth (Eichhornia crassipes) as a remediation tool for dyeeffluent pollution.. I.J.S.N., 1(2):172-178

[14] Hazra, M., Avishek, K and Pathak, G. 2015. Phytoremedial Potential of Typha latifolia, Eichornia crassipes and Monochoria hastata found in Contaminated Water Bodies Across Ranchi City (India). Int J Phytoremediation. 17(9):835 